\title{
KERJASAMA TIM DALAM PENINGKATAN KUALITAS PELAYANAN DI KANTOR DESA TIMORENG PANUA KECAMATAN PANCA RIJANG KABUPATEN SIDENRENG RAPPANG
}

\author{
Yenny Takdir \\ Fakultas IImu Sosial dan IImu Politik Universitas Muhammadiyah Rappang \\ Arsipfisip.ums@gmail.com
}

\begin{abstract}
Abstrak
Penelitian ini bertujuan untuk mengetahui Kerjasama Tim di Kantor Desa Timoreng Panua Kecamatan Panca Rijang Kabupaten Sidenreng Rappang, untuk mengetahui Kualitas Pelayanan di Kantor Desa Timoreng Panua Kecamatan Panca Rijang Kabupaten Sidenreng Rappang dan Untuk mengetahui Peran Kerjasama Tim dalam Peningkatan Kualitas Pelayanan di Kantor Desa Timoreng Panua Kecamatan Panca Rijang Kabupaten Sidenreng Rappang. Populasi dalam penelitian ini adalah jumlah kepala keluarga yakni 547 Orang. Pengambilan sampel menggunakan teknik sampel acak dengan menggunakan rumus Yount dengan mengambil $10 \%$, sehingga sampelnya berjumlah 55 Orang. Tekhnik pengumpulan data yang digunakan dalam penelitian ini adalah observasi, wawancara, kuisioner dan studi kepustakaan. Data yang terkumpul kemudian digunakan cara teknik analisis kuantitatif dengan tabel frekuensi. Hasil penelitian menunjukkan bahwa Kerjasama Tim di Kantor Desa Timoreng Panua Kecamatan Panca Rijang Kabupaten Sidenreng Rappang dikategorikan baik dengan rata-rata persentase 66,4\%. Indikator yang mempunyai nilai tertinggi adalah Kerjasama aparatur Desa Timoreng Panua dalam memberikan pelayanan kepada masyarakat (Kerjasama). Kualitas Pelayanan Kualitas Pelayanan di Kantor Desa Timoreng Panua Kecamatan Panca Rijang Kabupaten Sidenreng Rappang dikategorikan baik dengan rata-rata persentase $66,28 \%$. Indikator yang mempunyai nilai tertinggi adalah Kemudahan informasi pelayanan bagi masyarakat Desa Timoreng Panua. Peran Kerjasama Tim dalam Peningkatan Kualitas Pelayanan di Kantor Desa Timoreng Panua Kecamatan Panca Rijang Kabupaten Sidenreng Rappang dikategorikan baik dengan persentase $65 \%$.
\end{abstract}

Kata Kunci: Kerjasama Tim dan Kualitas Pelayanan

\begin{abstract}
This study aims to find out the Team Cooperation at the Timoreng Panua Village Office in Panca Rijang District, Sidenreng Rappang District, to find out the Quality of Service at the Timoreng Panua Village Office in Panca Rijang District, Sidenreng Rappang District and to find out the Role of Team Cooperation in Improving Service Quality at the Timoreng Panua District Office Panca Rijang, Sidenreng Rappang Regency. The population in this study is the number of family heads, which is 547 people. Sampling uses a random sample technique using the Yount formula by taking $10 \%$, so the sample is 55 people. Data collection techniques used in this study were observation, interviews, questionnaires and literature studies. The collected data is then used in quantitative analysis techniques with frequency tables. The results showed that Team Cooperation at the Timoreng Panua Village Office in Panca Rijang District, Sidenreng Rappang Regency was categorized as good with an average percentage of $66.4 \%$. The indicator that has the highest value is the division of labor of the Timoreng Panua village apparatus in providing services to the community (Cooperation). The Quality of Service Quality in the Office of the Village of Timoreng Panua, Panca Rijang Subdistrict, Sidenreng Rappang Regency is categorized good with an average percentage of $66.28 \%$. The indicator that has the highest value is the ease of information service for the people of Timoreng Panua Village. The Role of Team Cooperation in Improving Service Quality in the Office of the Village of Timoreng
\end{abstract}


p-ISSN 2302-0970

e-ISSN 2723-0201

Panua, Panca Rijang Subdistrict, Sidenreng Rappang Regency is categorized as good with a percentage of $65 \%$.

Keywords: Team Cooperation and Service Quality 


\section{A. Pendahuluan}

Pelayanan merupakan tugas utama yang hakiki dari sosok aparatur, sebagai abdi negara dan abdi masyarakat. Tugas ini telah jelas digariskan dalam pembukaan UUD 1945 alinea keempat, yang meliputi 4 (empat) aspek pelayanan pokok aparatur terhadap masyarakat, yaitu melindungi segenap bangsa Indonesia dan seluruh tumpah darah Indonesia, memajukan kesejahteraan umum, mencerdaskan kehidupan bangsa dan melaksanakan ketertiban dunia yang berdasarkan kemerdekaan, perdamaian abadi dan keadilan sosial. Dan diperjelas lagi dalam Keputusan Menteri Pendayagunaan Aparatur Negara No. 63 tahun 2003 yang menguraikan pedoman umum penyelenggaraan pelayanan public. Pelayanan sebagai proses pemenuhan kebutuhan melalui aktivitas orang lain secara lansung, merupakan konsep yang senantiasa aktual dalam berbagai aspek kelembagaan. Bukan hanya pada organisasi bisnis, tetapi telah berkembang lebih luas pada tatanan organisasi pemerintah.

Dewasa ini kehidupan masyarakat mengalami banyak perubahan sebagai akibat dari kemajuan yang telah dicapai dalam proses pembangunan sebelumnya dan kemajuan yang pesat dalam ilmu pengetahuan dan teknologi. Perubahan yang dapat dirasakan sekarang ini adalah terjadinya perubahan pola pikir masyarakat ke arah yang semakin kritis. Hal itu dimungkinkan, karena semakin hari warga masyarakat semakin cerdas dan semakin memahami hak dan kewajibannya sebagai warga. Kondisi masyarakat yang demikian menuntut hadirnya pemerintah yang mampu memenuhi berbagai tuntutan kebutuhan dalam segala aspek kehidupan mereka, terutama dalam mendapatkan pelayanan yang sebaik-baiknya dari pemerintah. Pemberian palayanan yang memenuhi standar yang telah ditetapkan memang menjadi bagian yang perlu dicermati. Saat ini masih sering dirasakan bahwa kualitas pelayanan minimum sekalipun masih jauh dari harapan masyarakat. Yang lebih memprihatinkan lagi, masyarakat hampir sama sekali tidak memahami secara pasti tentang pelayanan yang seharusnya diterima dan sesuai dengan prosedur pelayanan yang baku oleh pemerintah. Masyarakatpun enggan mengadukan apabila menerima pelayanan yang buruk, bahkan hampir pasti mereka pasrah menerima layanan seadanya. Kenyataan semacam ini terdorong oleh sifatpublic goods menjadi monopoli pemerintah khususnya dinas/instansi pemerintah daerah dan hampir tidak ada pembanding dari pihak lain. Praktek semacam ini menciptakan kondisi yang merendahkan posisi tawar dari masyarakat sebagai penggunan jasa pelayanan dari pemerintah, sehingga memaksa masyarakat mau tidak mau menerima dan menikmati pelayanan yang kurang memadai tanpa protes.

Satu hal yang belakangan ini sering dipermasalahkan adalah dalam bidang publik service (Pelayanan Umum), terutama dalam hal kualitas atau mutu pelayanan aparatur pemerintah kepada masyarakat. Pemerintah sebagai service provider (Penyedia Jasa) bagi masyarakat dituntut untuk memberikan pelayanan yang berkualitas. Apalagi pada era otonomi daerah, kulitas dari pelayanan aparatur pemerintah akan semakin ditantang untuk optimal dan mampu menjawab tuntutan yang semakin tinggi dari masyarakat, baik dari segi kulitas maupun dari segi kuantitas pelayanan. Pentingnya kerjasama tim dalam kualitas pelayana adalah untuk mencapai tujuan dengan hasil yang memuaskan dan sesuai dengan apa yang diharapkan bersama. Seorang pemimpin tim mendapatkan banyak manfaat dari anggota lain dari tim, mempengaruhi, membimbing, memberi inspirasi dimana semuanya dapat mempengaruhi motivasi para anggota tim dalam menggunakan cara-cara positif. Jika pemimpin tidak dapat membangun kerjasama tim yang baik, otomatis akan menghambat untuk mencapai tujuan atau bahkan menghasilkan hasil kinerja yang tidak sesuai apa yang diinginkan. Pemimpin tim yang efektif tidak hanya bicara saja tetapi mereka juga menunjukkan, membenarkan, mendorong, dan mendesak setiap langkah.

Kerjasama dalam tim akan menjadi suatu daya dorong yang memiliki energi dan sinergisitas bagi individu. Tanpa kerjasama tim yang baik tidak akan memunculkan ideide cemerlang. Sebagaimana yang dinyatakan Bachtiar (2004) bahwa kerja sama tim merupakan sinergisitas kekuatan dari beberapa orang dalam mencapai satu tujuan yang diinginkan. Kerjasama tim akan menyatukan kekuatan ide-ide yang akan mengantarkan pada kesuksesan. Kerjasama tim adalah suatu unit yang terdiri atas dua 
orang atau lebih yang berinteraksi dan mengkoordinasi kerja mereka untuk tujuan tertentu. Penelitian Cohen dan Bailey (Judeh, 2011) menyebutkan organisasi sering mengandalkan kerjasama tim untuk perbaikan terus menerus produk dan jasa, dan juga dari semua fungsi organisasi lannya. Sebagai contoh, beberapa perkiraan mengklaim $80 \%$ dari organisasidengan 100 atau lebih pegawai bergantung pada tim dan kelompok untuk pekerjaan yang diberikan. Organisasimemerlukan kerjasama pegawai untuk kemajuan perusahaannya, oleh karena itu masing-masing anggota mau menerima dan mampu bekerjasama dengan anggota lainnya di dalam tim tersebut (Munandar: 2008).

Berdasarkan penjelasan mengenai kerjasama tim dari berbagai teori di atas, maka juga dapat di ambil sebuah kesimpulan bahwa kerjasama tim adalah kemampuan individu dalam melakukan kerjasama dengan baik untuk mencapai tujuan bersama di dalam tim yang saling percaya dan mendukung serta bertanggungjawab terhadap tugas-tugas yang telah diberikan. Pegawai dalam organisasi sangatlah penting dalam memberikan pelayanan, kerjasama tim yang rendah merupakan salah satu hal yang menyebabkan seseorang mudah mengabaikan pekerjaan seperti tidak saling percaya dan mendukung kurang pengetahuan atau skill, saling melempar tanggungjawab dan saling ketergantungan. Padahal dari sisi organisasi sendiri, kerjasama tim sangat bergantung pada anggotanya. Apabila yang melakukan hal ini adalah anggota yang berkualitas dan dianggap dapat membawa kebaikan bagi organisasi, tentu saja kondisi ini akan membawa kerugian tersendiri bagi organisasi.

Kondisi di atas sejalan mengenai kerjasama tim yang merupakan sarana penggabungan berbagai talenta dan dapat memberikan solusi inovatif suatu pendekatan yang mapan di Kantor Desa Timoreng Panua. Selain itu, beraneka ragamnya keterampilan dan pengetahuan yang dimiliki oleh anggota dapat memberi keunggulan yang lebih besar dibandingkan kerja seorang diri. Rentangan keterampilan dan pengetahuan yang dimiliki pegawai di Kantor Desa Timoreng Panua dan pengawasan diri yang diperlihatkan oleh masing-masing tim memungkinkan untuk diberikan suatu tugas dan tanggungjawab. Gejala lain yang muncul dari rendahnya kerjasama tim adalah pencapaian produktivitas yang terlambat dari waktu yang telah ditetapkan, tidak disiplin dalam menjalankan peraturan, perilaku kerja yang tidak mendukung kerja yang positif serta ketidakterbukaan yang dirasakan mengganggu kelancaran kerja dalam tim. Kerjasama tim di Kantor Desa Timoreng Panua Kecamatan Panca Rijang akan meningkatkan performa kinerjanya sehingga secara signifikan akan terkait dengan keberhasilan kinerja terhadap target yang ditentukan dan pada akhirnya menjadikan tim yang efektif.

Masalah dalam melayani di Kantor Desa Timoreng Panua Kecamatan Panca Rijang adalah masalah yang sangat penting. Tanpa adanya pelayanan yang baik tidak mungkin dapat menghasilkan sesuatu bagi masyarakat yang kompetitif. Peningkatan pelayanan mempunyai implikasi yang positif bagi Kantor Desa Timoreng Panua itu sendiri, artinya dapat menghasilkan kuantitas dan kualitas pelayanan yang optimal. Selain itu juga, mempunyai implikasi yang positif terhadap kualitas kehidupan pegawai, karena memberikan sumbangan terhadap peningkatan kualitas hidup pegawai. Kualitas pelayanan pegawai akan meningkat bila didukung oleh penerapan sistem manajemen kinerja dan sistem pengembangan karir yang baik dan efektif serta penerapan kerjasama tim dan partisipasi pegawai.

Berdasarkan hasil observasi di Kantor Desa Timoreng Panua pada tanggal 4 Februari 2019 bahwa kurangnya kualitas kerja pelayanan pegawai di Kantor Desa Timoreng Panua Kecamatan Panca Rijang tampak dari permasalahan-permasalahan yang muncul. Masalah bagi kantor desa Timoreng panua adalah masalah yang sangat penting. Tanpa adanya kualitas pelayanan yang baik tidak mungkin dapat menghasilkan pelayanan yang memuaskan .Peningkatan kualitas pelayanan mempunyai implikasi yang positif, artinya dapat menghasilkan pelayanan yang optimal bagi masyarakat dan kinerja pegawai akan meningkat. Permasalahan yang dirasakan oleh salah satu masyarakat yang di wawancarai adalah menurunnya kualitas pelayanan para pegawai, hal ini ditandai dengan Tugas pegawai seringkali saling melempar tanggung jawab dan saling menyalahkan jika terjadi permasalahan, 
Terkadang aparatur acuh ketika masyarakat ingin dilayani, Tidak adanya pusat informasi pelayanan sehingga terkadang masyarakat bingung tentang berkas apa yang perlu dilengkapi untuk dilayani dalam pembuatan Kartu Tanda Penduduk atau Kartu Keluarga.

Sehubungan dengan masalah di atas maka dengan ini peneliti tertarik untuk meneliti Peran Kerjasama Tim dalam Peningkatan Kualitas Pelayanan di Kantor Desa Timoreng Panua Kecamatan Panca Rijang Kabupaten Sidenreng Rappang dengan tujuan Untuk mengetahui Kerjasama Tim di Kantor Desa Timoreng Panua Kecamatan Panca Rijang Kabupaten Sidenreng Rappang, Untuk mengetahui Kualitas Pelayanan di Kantor Desa Timoreng Panua Kecamatan Panca Rijang Kabupaten Sidenreng Rappang dan Untuk mengetahui Peran Kerjasama Tim dalam Peningkatan Kualitas Pelayanan di Kantor Desa Timoreng Panua Kecamatan Panca Rijang Kabupaten Sidenreng Rappang.

\section{Konsep Kerjasama}

Menurut Lewis Thomas dan Elaine B. Johnson ( 2014:164) kerjasama adalah pengelompokan yang terjadi di antara makhlukmakhluk hidup yang kita kenal. Kerja sama atau belajar bersama adalah proses beregu (berkelompok) di mana anggotaanggotanya mendukung dan saling mengandalkan untuk mencapai suatu hasil mufakat. Ruang kelas suatu tempat yang sangat baik untuk membangun kemampuan kelompok (tim), yang anda butuhkan kemudian di dalam kehidupan. Menurut Soejono Soekamto dalam Anjawaningsih (2006) menerangkan bahwa kerjasama merupakan "Suatu kegiatan yang dilakukan secara bersama-sama oleh lebih dari satu orang. Kerjasama bisa bermacam- macam bentuknya, namun semua kegiatan yang dilakukan diarahkan guna mewujudkan tujuan bersama." Sesuai dengan kegiatannya, maka kegiatan yang terwujud ditentukan oleh suatu pola yang disepakati secara besama- sama. Misalnya kerjasama dibidang pendidikan, kerjasama ini tentunya dilakukan oleh orangorang yang berada dilingkungan pendidikan yang sama- sama memiliki pandangan dan tujuan yang sama.

Tim Kerja adalah kelompok orang yang usaha-usaha individualnya menghasilkan kinerja lebih tinggi daripada jumlah masukan individual (Stephen, Timothy, 2012:406). Hal ini memiliki pengertian bahwa kinerja yang dicapai oleh sebuahtim lebih baik daripada kinerja perindividu disuatu organsasi. Menurut Hughes (2012: 366) teori pembentukan tim harus melewati 4 tahap pembentukan yaitu: tahap forming (pembentukan), tahap storming (goncangan), tahap norming (membangun norma) dan tahap performing (berkinerja). Teori ini tidak dapat diaplikasikan begitu saja kepada masyarakat Indonesia terutama masyarakat suku jawa yang bersifat kolektivistik.

Allen (2004:21) kerja tim atau tim kerja adalah orang yang sportif, sensitive, dan senang bergaul, serta mampu mengenali aliran emosi yang terpendam dalam tim dengan sangat jelas. Tim kerja menghasilkan sinergi positif melalui usaha yang terkoordinasi.Usaha-usaha individual mereka menghasilkan satu tingkat kinerja yang lebih tinggi daripada jumlah masukan individual. Penggunaan tim secara ekstensif menghasilkan potensi bagi sebuah organisasi untuk membuahkan banyak hasil yang lebih besar tanpa peningkatan masukan. Kinerja tim akan lebih unggul daripada kinerja individu jika tugas yang harus dilakukan menuntut ketrampilan ganda. Williams (2008) membagi ada 5 (lima) hal yang menunjukkan peranan anggota dalam membangun kerja tim yang efektif, yaitu:

a. Para anggota mengerti dengan baik tujuan tim dan hanya dapat dicapai dengan baik pula dengan dukungan bersama, dan oleh karena itu mempunyai rasa saling ketergantungan, rasa saling memiliki tim dalam melaksanakan tugas.

b. Para anggota menyumbang keberhasilan tim dengan menerapkan bakat dan pengetahuannya untuk sasaran tim, dapat bekerja dengan secara terbuka, dapat mengekspresikan gagasan, opini dan ketidaksepakatan, peranan dan pertanyaannya disambut dengan baik.

c. Para anggota berusaha mengerti sudut pandang satu sama lain, didorong untuk mengembangkan keterampilannya dan menerapkan pada pekerjaan, untuk itu mendapat dukungan dari tim.

d. Para anggota mengakui bahwa konflik adalah hal yang normal, atau hal yang biasa, dan berusaha memecahkan konflik tersebut dengan cepat dan konstruktif (bersifat memperbaiki). 
e. Para anggota berpartisipasi dalam keputusan tim, tetapi mengerti bahwa pemimpin mereka harus membuat peraturan akhir setiap kali tim tidak berhasil membuat suatu keputusan, dan peraturan akhir itu bukan merupakan persesuaian.

Manurung (2013:23) mengemukakan bahwa indikator-indikator kerjasama tim adalah :

a. Kerjasama.

Kerjasama dilakukan oleh sebuah tim agar lebih efektif daripada kerja secara individual. Menurut West yaitu "telah banyak riset membuktikan bahwa kerjasama secara berkelompok mengarah pada efisiensi dan efektivitas yang lebih baik, hal ini sangat berbeda dengan kerja yang dilaksanakan oleh perorangan". Indikator kerjasama menurut Fitri (2012:107) yakni:

1) Menggabungkan tenaga pribadi dan orang lain untuk mencapai tujuan yang ilmiah.

2) Membagi pekerjaan dengan orang lain dengan satu tujuan.

b. Kepercayaan.

Kepercayaan yang disebut dengan trust adalah keyakinan bahwa seseorang sungguh-sungguh dengan apa yang dikatakan dan dilakukannya.

1) Kepercayaan merupakan perkembangan dari pengalaman dan tindakan dimasa lalu.

2) Watak yang diharapkan dari mitra seperti dapat dipercaya dan dapat dihandalkan.

3) Kepercayan melibatkan kesediaan untuk menempatkan diri dalam resiko.

4) Kepercayaan melibatkan perasaan aman dan yakin pada diri mitra.

c. Kekompakan.

Pengertian mengenai kekompakan bahwa kekompakan adalah bekerja sama bersatu padu, teratur dan rapi dalam menghadapi suatu pekerjaan yang ditandai adanya saling tergantung satu sama lain. Ada 5 (lima) hal yang bisa menjadi bahan latihan kekompakan dalam sebuah tim, yaitu:

1) Komunikasi, meliputi kelancaran komunikasi, tepat dan akurat menyampaikan informasi, dan saling terbuka.

2) Respek satu sama lain, meliputi memahami kebutuhan dan
p-ISSN 2302-0970

e-ISSN 2723-0201

mendengarkan pendapat pihak lain, memberikan feedback konstruktif, serta member apresiasi.

3) Kesiapan menerima tantangan, juga kegigihan dan ketekunan dalam bekerja

4) Kerja sama, meliputi kemampuan memahami pentingnya komitmen, kepercayaan, penyelesaian masalah bersama, kejelasan tujuan, memberi dukungan dan motivasi, serta mengakui kesuksesan

5) Kepemimpinan, baik memimpin orang lain, tim, maupun memimpin diri sendiri.

Defenisi yang dirumuskan oleh Goeth

dan Davis yang dikutip Tjiptono (2012:51) bahwa kualitas merupakan suatu kondisi dinamis yang berhubungan dengan produk, jasa, manusia, proses, dan lingkungan yang memenuhi atau melebihi harapan. Sebaliknya, definisi kualitas yang bervariasi dari yang kontroversional hingga kepada yang lebih strategik. Unsur-unsur kualitas pelayanan yang dikutip dalam Saleh (2010:106) antara lain adalah sebagai berikut:

1) Penampilan. Personal dan fisik sebagaimana layanan kantor depan (resepsionis) memerlukan persyaratan seperti berpenampilan menarik, badan harus tegap/tidak cacat, tutur bahasa menarik, familiar dalam berperilaku, penampilan penuh percaya diri.

2) Tepat Waktu dan Janji. Secara utuh dan prima petugas pelayanan dalam menyampaikan perlu diperhitungkan janji yang disampaikan kepada pelanggan bukan sebaliknya selalu ingkar janji. Demikian juga waktu jika mengutarakan 7 hari selesai harus betul-betul dapat memenuhinya.

3) Kesediaan Melayani. Sebagiamana fungsi dan wewenang harus melayani kepada para pelanggan, konsekuensi logis petugas harus benar-benar bersedia melayani kepada para pelanggan.

4) Pengetahuan dan Keahlian. Sebagai syarat untuk melayani dengan baik, petugas harus mempunyai pengetahuan dan keahlian. Di sini petugas pelayanan harus memiliki tingkat pendidikan tertentu dan pelatihan tertentu yang diisyaratkan dalam jabatan serta memiliki pengalaman yang luas dibidangnya. 
5) Kesopanan dan Ramah Tamah. Masyarakat pengguna jasa pelayanan itu sendiri dan lapisan masyarakat baik tingkat status ekonomi dan sosial rendah maupun tinggi terdapat perbedaan karakternya maka petugas pelayanan masyarakat dituntut adanya keramahtamahan yang standar dalam melayani, sabar, tidak egois dan santun dalam bertutur kepada pelanggan.

6) Kejujuran dan Kepercayaan. Pelayanan ini oleh pengguna jasa dapat dipergunakan berbagai aspek, maka dalam penyelenggaraannya harus transparan dari aspek kejujuran, jujur dalam bentuk aturan, jujur dalam pembiayaan dan jujur dalam penyelesaian waktunya. Dari aspek kejujuran ini petugas pelayanan tersebut dapat dikategorikan sebagai pelayan yang dipercaya dari segi sikapnya, dapat dipercaya dari tutur katanya, dapat dipercayakan dalam menyelesaikan akhir pelayanan sehingga otomatis pelanggan merasa puas. Unsur pelayanan prima dapat ditambah unsur yang lain.

7) Kepastian Hukum. Secara sadar bahwa hasil pelayanan terhadap masyarakat yang berupa surat keputusan, harus mempunyai legitimasi atau mempunyai kepastian hukum. Bila setiap hasil yang tidak mempunyai kepastian hukum jelas akan mempengaruhi sikap masyarakat, misalnya pengurusan KTP, KK dan lain-lain bila ditemukan cacat hukum akan mempengaruhi kredibilitas instansi yang mengeluarkan surat legitimasi tersebut.

8) Keterbukaan. Secara pasti bahwa setiap urusan/kegiatan yang memperlakukan ijin, maka ketentuan keterbukaan perlu ditegakkan Keterbukaan itu akan mempengaruhi unsur-unsur kesederhanaan, kejelasan informasi kepada masyarakat.

9) Efisien. Dari setiap pelayanan dalam berbagai urusan, tuntutan masyarakat adalah efisiensi dan efektifitas dari berbagai aspek sumber daya sehingga menghasilkan biaya yang murah, waktu yang singkat dan tepat serta kualitas yang tinggi. Dengan demikian efisiensi dan efektifitas merupakan tuntutan yang harus diwujudkan dan perlu diperhatikan secara serius.
p-ISSN 2302-0970

e-ISSN 2723-0201

10) Biaya. Pemantapan pengurusan dalam pelayanan diperlukan kewajaran dalam penentuan pembiayaan, pembiayaan harus disesuaikan dengan daya beli masyarakat dan pengeluaran biaya harus transparan dan sesuai dengan ketentuan peraturan perundangundangan.

11) Tidak Rasial. Pengurusan pelayanan dilarang membeda-bedakan kesukuan, agama, aliran dan politik dengan demikian segala urusan harus memenuhi jangkauan yang luas dan merata.

12) Kesederhanaan. Prosedur dan tata cara pelayanan kepada masyarakat untuk diperhatikan kemudahan, tidak berbelit-belit dalam pelaksanaan.

\section{Kualitas Pelayanan Publik}

Fitzsimmons dan Fitzsimmons dalam Sinambela ( $2014: 7$ ) berpendapat terdapat lima indikator kualitas pelayanan publik diantaranya :

a) Reliability yang ditandai pemberian pelayanan yang tepat dan benar

b) Tangibles yang ditandai dengan penyediaan yang memadai sumber daya manusia dan sumber daya lainnya.

c) Responsiviness, yang ditandai dengan keinginan melayani masyarakat dengan cepat.

d) Assurance yang ditandai dengan tingkat perhatian terhadap etika dan moral dalam memberikan pelayanan

e) Empati yang ditandai dengan tingkat kemauan untuk mengetahui keinginan dan kebutuhan masyarakat.

\section{B. METODE PENELITIAN}

Lokasi penelitian akan dilakukan di Kantor Desa Aka-Akae Kecamatan Wattang Sidenreng Kabupaten Sidenreng Rappang. Lokasi ini di pilih karena sesuai dengan masalah yang akan diteliti dan akan dimulai bulan Maret-April 2019. Penelitian memiliki dua variabel, variabel pertama disebut varibel bebas yakni birokrasi transformasional dan variabel kedua disebut variabel terikat yakni kinerja. Metode penelitian yang digunakan dalam penelitian ini adalah metode penelitian deskriptif kuantitatif. Metode penelitian kuantitatif Sugiyono (2014:8) adalah sebagai berikut: metode penelitian kuantitatif dapat diartikan sebagai metode penelitian yang berlandaskan pada sample filsafat positivisme, digunakan untuk meneliti pada 
populasi atau sample tertentu, pengumpulan data menggunakan instrument penelitian, analisis data kuantitatif/statistik, dengan tujuan untuk menguji hipotesis yang telah ditetapkan.

Adapun teknik pengumpulan data yang digunakan penulis dalam mengumpulkan data adalah Observasi, Wawancara, Kajian Kepustakaan, dan Kuesioner/Angket. Adapun tahapan-tahapan yang dilakukan penulis dalam analisis data adalah Reduksi data, Tabulasi data adalah proses perumusan data yang telah diperoleh dalam bentuk tabel, peta, bagan dan struktur sehingga data tersebut menjadi jelas dan mempermudah pemahaman.

\section{HASIL DAN PEMBAHASAN}

1. Kerjasama Tim di Kantor Desa Timoreng Panua Kecamatan Panca Rijang Kabupaten Sidenreng Rappang.

Berdasarkan dengan data akumulasi di atas maka diketahui Kerjasama Tim di Kantor Desa Timoreng Panua Kecamatan Panca Rijang Kabupaten Sidenreng Rappang dikategorikan baik dengan rata-rata persentase $66,4 \%$. Indikator yang mempunyai nilai tertingg adalah Kerjasama aparatur Desa Timoreng Panua dalam memberikan pelayanan kepada masyarakat (Kerjasama). Manfaat kerjasama sangat besar. Deskripsi kerja pertama-tama digunakan sebagai dasar untuk penilaian jabatan, kerjasama dan deskripsi kerja juga dikenal pimpinan sebagai dasar untuk memimpin. Kerjasama merupakan dokumen formal organisasi yang berisi ringkasan informasi penting mengenai kerja untuk memudahkan pelayanan kepada masyarakat Desa Timoreng Panua. Kerjasama diwujudkan untuk mengelompokan tugas sesuai dengan tanggung jawab masingmasing personil atau unit kerja. Dengan jadwal ataupun definisi pembagian pekerjaan akan disesuaikan dengan kemampuan seorang atau unit lebih terlihat,dan yang jelas lebih mengurangi tingkat kerumitan.Yang pastinya akan lebih efektif dan efisiensi.

Manfaat kerjasama yaitu agar suatu pekerjaan dapat terselenggara dengan baik sesuai rencana dan dapat diketahui dengan jelas tujuan organisasi, dan pegawai yanga bertanggung jawab atas terselenggaranya pekerjaan tersebut. Manfaat kerjasama adalah Memudahkan seseorang melakukan pekerjaanya atau tugasnya tanpa menunggu
p-ISSN 2302-0970

e-ISSN 2723-0201

perintah atau komando, Diketahui dengan jelas batas wewenang dan tangggung jawab dari pekerjaan itu, Tidak meragukan dalam pemberian tugas atau pelaksanaan tugas, Memudahkan pengawasan, Tidak terjadinya simpang siur atau benturan dalam pelaksanaan pekerjaan, Menjadi dasar pertimbangan dalam penentaun kebutuhan pendidikan

2. Kualitas Pelayanan di Kantor Desa Timoreng Panua Kecamatan Panca Rijang Kabupaten Sidenreng Rappang.

Berdasarkan dengan data akumulasi di atas maka diketahui Kualitas Pelayanan di Kantor Desa Timoreng Panua Kecamatan Panca Rijang Kabupaten Sistem informasi desaenreng Rappang dikategorikan baik dengan rata-rata persentase 66,28\%. Indikator yang mempunyai nilai tertinggi adalah Kemudahan informasi pelayanan bagi masyarakat Desa Timoreng Panua. Sistem Informasi Desa merupakan sebuah aplikasi yang digunakan untuk mengelola data di Desa Timoreng Panua Sistem Informasi Desa yang baik dirancang sebagai alat dukung untuk pelayanan di kantor desa. Fungsi yang dapat dilakukan antara lain administrasi kependudukan, perencanaan, pelaporan, inventarisir aset kantor desa, inventarisir sarana prasaranan di desa, pengelolaan anggaran desa, layanan publik, dan lain sebagainya. Adapun, manfaat dari penggunaan Sistem Informasi Desa ini sangat banyak. Dianataranya.

Mengelola data kependudukan secara efisien dan valid. Setelah menggunakan sitem informasi desa, pemerintah desa akan lebih cepat saat mencari data penduduk, tidak perlu bolak balik untuk membuka kartu keluarga. Pada Sistem Informasi Desa yang dikembangkan oleh puskomedia dirancang dengan fitur robot, saat ada data yang kosong ataupun bermasalah, sang robot akan memberitahukannya kepada operator. Fitur validasi data menjadi keunggulan dari Sistem Informasi Desa dibandingkan dengan menggunakan data kertas atau spreadsheet saja. Pelayanan cepat. Setelah menggunakan Sistem Informasi Desa, pelayanan cetak surat menjadi lebih cepat. Robot di Panda dirancang untuk mempermudah cetak surat. Operator hanya perlu mencari nama penduduk, lalu biarkanlah robot panda yang akan bekerja untuk membuat surat yang diperlukan. Saat mencari data penduduk, Pada Sistem 
Informasi Desa akan bekerja untuk mencarikan data sesuai dengan instruksi operator. Mencari secara spesifik misalkan perempuan, belum menikah, usia 25 tahun, pendidikan SMA. Sistem Informasi Desa bekerja untuk mempermudah transparansi desa kepada warga. Pada Sistem Informasi Desa terdapat fitur yang berfungsi ganda. Di saat pemerintah desa menginput dana APB Desa untuk pelaporan, saat itu juga transparansi anggaran akan muncul pada website desa.

Pelaporan Kegiatan Pemerintah Desa. Sistem Informasi Desa mempermudah untuk pelaporan bagi pemerintah desa kepada masyarakatnya. Selama ini, Pemerintah Desa sudah sering melaporkan segala kegiatannya melalui media sosial. Hanya saja pelaporan tersebut tidak terorganisir, misalkan hanya melalui akun facebook pribadi milik kepala desa. Jenis pelaporan seperti ini hanya akan berdampak hanya kepada akun yang menjadi teman kepala desa di facebook. Teknologi Panda hadir untuk merapikan kebiasaan tersebut. Meskipun hanya dilakukan lewat media sosial, pelaporan tersebut akan sinkron ke website sehingga dapat dilihat oleh siapa saja, tanpa harus menjadi teman di facebook.

3. Peran Kerjasama Tim dalam Peningkatan Kualitas Pelayanan di Kantor Desa Timoreng Panua Kecamatan Panca Rijang Kabupaten Sidenreng Rappang.

Jumlah dari kedua variabel yaitu kerjasama tim $(X)$ dalam Kualitas Pelayanan (Y) di Desa Timoreng Panua Kecamatam Panca Rijang Kabupaten Sidenreng Rappang maka dapat dilihat dari Rumus dibawah ini dengan menggunakan Rumus Hasil Ideal sebagai berikut :

$$
=\frac{534+917}{5 \times 8 \times 55} \times 100
$$

$$
=\frac{534+917}{5 \times 8 \times 55}=\frac{1.451}{2.200}=0.65 \times 100 \%=65 \%
$$

Jika dilihat dari Rumus diatas maka terdapat $65 \%$ kurang dari $100 \%$ dimana $65 \%$ merupakan Kategori "Baik". Berdasarkan dengan hasil ideal di atas maka diketahui bahwa Peran Kerjasama Tim dalam Peningkatan Kualitas Pelayanan di Kantor Desa Timoreng Panua Kecamatan Panca Rijang Kabupaten Sidenreng Rappang dikategorikan baik dengan persentase $65 \%$. Jadi sisa dari $65 \%$ yakni $35 \%$ adalah Masalah dalam melayani di Kantor Desa
p-ISSN 2302-0970

e-ISSN 2723-0201

Timoreng Panua Kecamatan Panca Rijang adalah masalah yang sangat penting. Tanpa adanya pelayanan yang baik tidak mungkin dapat menghasilkan sesuatu bagi masyarakat yang kompetitif. Peningkatan pelayanan mempunyai implikasi yang positif bagi Kantor Desa Timoreng Panua itu sendiri, artinya dapat menghasilkan kuantitas dan kualitas pelayanan yang optimal. Selain itu juga, mempunyai implikasi yang positif terhadap kualitas kehidupan pegawai, karena memberikan sumbangan terhadap peningkatan kualitas hidup pegawai. Kualitas pelayanan pegawai akan meningkat bila didukung oleh penerapan sistem manajemen kinerja dan sistem pengembangan karir yang baik dan efektif serta penerapan kerjasama tim dan partisipasi pegawai.

\section{KESIMPULAN}

Berdasarkan dengan hasil penelitian maka adapun Simpulan yang dapat kami kemukakan adalah sebagai berikut :

1. Kerjasama Tim di Kantor Desa Timoreng Panua Kecamatan Panca Rijang Kabupaten Sidenreng Rappang dikategorikan baik dengan rata-rata persentase $66,4 \%$. Indikator yang mempunyai nilai tertingg adalah Pembagian kerja aparatur Desa Timoreng Panua dalam memberikan pelayanan kepada masyarakat (Kerjasama). Pembagian kerja akan memberikan ketegasan dan standar tugas yang harus dicapai oleh seorang pejabat yang memegang jabatan tersebut. Pembagian pekerjaan ini menjadi dasar untuk menetapkan spesifikasi pekerjaan dan evaluasi pekerjaan bagi pejabat yang memegang jabatan itu. Pembagian kerja yang kurang jelas akan mengakibatkan seorang pejabat kurang mengetahui tugas dan tanggung jawabnya. Hal ini mengakibatkan pekerjaan menjadi tidak beres. Disinilah letak pentingnya peranan pembagian kerja.

2. Kualitas Pelayanan Kualitas Pelayanan di Kantor Desa Timoreng Panua Kecamatan Panca Rijang Kabupaten Sidenreng Rappang dikategorikan baik dengan ratarata persentase $66,28 \%$. Indikator yang mempunyai nilai tertinggi adalah Kemudahan informasi pelayanan bagi masyarakat Desa Timoreng Panua (Empati). Kemudahan informasi ini melalui sistem informasi desa. Sistem Informasi 
Desa merupakan sebuah aplikasi yang digunakan untuk mengelola data di Desa Timoreng Panua Sistem Informasi Desa yang baik dirancang sebagai alat dukung untuk pelayanan di kantor desa. Fungsi yang dapat dilakukan antara lain administrasi kependudukan, perencanaan, pelaporan, inventarisir aset kantor desa, inventarisir sarana prasaranan di desa, pengelolaan anggaran desa, layanan publik, dan lain sebagainya

3. Peran Kerjasama Tim dalam Peningkatan Kualitas Pelayanan di Kantor Desa Timoreng Panua Kecamatan Panca Rijang Kabupaten Sidenreng Rappang dikategorikan baik dengan persentase $65 \%$.

\section{E. DAFTAR PUSTAKA}

Aan Komariah, Engkoswara. 2012. Administrasi Pendidikan,. Bandung: Alfabeta.

Abu, Ahmadi. 2007. Psikologi Sosial. Jakarta : Rineka Cipta.

Ahmad, Jamaluddin. 2015. Metode Penelitian Administrasi Publik: Teori dan Aplikasi . Gava Media : Yogyakarta.

Allen, Alexander. Jean, 2004. Strategi Membangun Tim Tangguh. Jakarta: Prestasi Pustaka Publisher.

Anjawaningsih, 2006. Kerjasama. Jakarta. Gramedia Jakarta

Arikunto, S. 2013. Prosedur Penelitian: Suatu Pendekatan Praktik. Jakarta: Rineka Cipta.

Agus Zaenal Fitri. 2012. Pendidikan Karakter Berbasis Nilai dan Etika di Sekolah,. Jakarta: Ar-Ruzz Media.

Daft, Richard L, 2010. Era Baru Manajemen, Edisi 9, Buku 2, Salemba Empat,. Jakarta.

Hariandja, Marihot Tua Efendi. 2006. Perilaku Organisasi, Bandung, Unpar. Press
Http://equityworld-f.com/pentingnya-

menjalin-kerjasama-tim-dalamorganisasi/

Hughes, dkk. 2012. Leadership: Memperkaya Pelajaran dari Pengalaman, edisi 7. Jakarta: Salemba Humanika.

Johnson, Elaine B. 2014. Contextual Teaching and Learning: Menjadikan Kegiatan Belajar Mengajar Mengasyikan dan Bermakna. Bandung: Kaifa.

Keban. 2009.prinsip kerjasama. Jakarta. Rosda

Mahfuz Judeh, 2011. Role Ambiguity and Role Conflict as Mediators of The Relationship between Socialization and Organizational Commitment. Vol. 4, No. 3, International Businnes Research. (Terjemahan).

Manurung, Surya.2013. Kompleksitas Kepatuhan Pajak. Direktorat Jenderal Pajak

Munandar, Ashar Sunyoto. 2008. Psikologi Industri dan Organisasi. Universitas. Indonesia, Jakarta.

Nazir, 2011. Metode Penelitian. Cetakan 6. Ghalia : Bogor

Robbins, Stephen P. dan Timothy A. Judge. 2012. Perilaku Organisasi. Jakarta: Salemba Empat.

Saleh, A. Muwafik . 2010. Public Service : Communication. UMM press. Malang

Sinambela, Lijak , dkk. 2014. Reformasi Pelayanan Publik. Bumi Aksara: Jakarta

Stanton, William J (Swasta \& Handoko). 2008. Manajemen Pemasaran, Analisis Perilaku Konsumen http://library.um.ac.id (diakses tanggal 11 November 2012 pukul 14.00).

Tjiptono, Fandy. 2012. Service Management Mewujudkan Layanan Prima. Andi Offset : Yogyakarta 